\title{
Article \\ Removal of Hexavalent Chromium(VI) from Wastewater Using Chitosan-Coated Iron Oxide Nanocomposite Membranes
}

\author{
Jung Eun Park ${ }^{1,+}{ }^{,}$Jun-Ho Shin ${ }^{1,+}$, Wonzin Oh ${ }^{2}$, Sang-June Choi ${ }^{2}$, Jeongju Kim ${ }^{3}{ }^{\circledR}$, Chorong Kim ${ }^{3}$ \\ and Jongho Jeon $1, * \mathbb{C}$ \\ 1 Department of Applied Chemistry, College of Engineering, Kyungpook National University, \\ Daegu 41566, Korea; pje1204@knu.ac.kr (J.E.P.); sa011107@knu.ac.kr (J.-H.S.) \\ 2 School of Architectural, Civil, Environmental, and Energy Engineering, Kyungpook National University, \\ Daegu 41566, Korea; wonzin@knu.ac.kr (W.O.); sjchoi@knu.ac.kr (S.-J.C.) \\ 3 Korea Hydro \& Nuclear Power Co., Ltd., Central Research Institute, Daejeon 34101, Korea; \\ jeongju.kim@khnp.co.kr (J.K.); chorong.kim@khnp.co.kr (C.K.) \\ * Correspondence: jeonj@knu.ac.kr; Tel.: +82-53-950-5584 \\ + These authors contributed equally to this work.
}

check for updates

Citation: Park, J.E.; Shin, J.-H.; Oh, W.; Choi, S.-J.; Kim, J.; Kim, C.; Jeon, J. Removal of Hexavalent Chromium(VI) from Wastewater Using Chitosan-Coated Iron Oxide Nanocomposite Membranes. Toxics 2022, 10, 98. https://doi.org/ $10.3390 /$ toxics 10020098 Academic Editors: Mei-Rong Huang and Xin-Gui Li

Received: 30 December 2021 Accepted: 16 February 2022 Published: 19 February 2022

Publisher's Note: MDPI stays neutral with regard to jurisdictional claims in published maps and institutional affiliations.

Copyright: (C) 2022 by the authors. Licensee MDPI, Basel, Switzerland. This article is an open access article distributed under the terms and conditions of the Creative Commons Attribution (CC BY) license (https:// creativecommons.org/licenses/by/ $4.0 /)$.

\begin{abstract}
Chromium is a toxic and carcinogenic heavy metal that originates from various human activities. Therefore, the effective removal of chromium from aqueous solutions is an extremely important global challenge. Herein, we report a chitosan-coated iron oxide nanoparticle immobilized hydrophilic poly(vinylidene) fluoride membrane (Chi@ $\left.\mathrm{Fe}_{2} \mathrm{O}_{3}-\mathrm{PVDF}\right)$ which can potentially be used for efficient removal of hexavalent chromium(VI) by a simple filtration process. Membrane filtration is an easy and efficient method for treating large volumes of water in a short duration. The adsorption experiments were conducted by batch and continuous in-flow systems. The experimental data showed rapid capture of hexavalent chromium $(\mathrm{Cr}(\mathrm{VI}))$ which can be explained by the pseudosecond-order kinetic and Langmuir isotherm model. The nanocomposite membrane exhibited high adsorption capacity for $\mathrm{Cr}(\mathrm{VI})(14.451 \mathrm{mg} / \mathrm{g}$ in batch system, $14.104 \mathrm{mg} / \mathrm{g}$ in continuous in-flow system). Moreover, its removal efficiency was not changed significantly in the presence of several competing ions, i.e., $\mathrm{Cl}^{-}, \mathrm{NO}_{3}{ }^{-}, \mathrm{SO}_{4}{ }^{2-}$, and $\mathrm{PO}_{4}{ }^{3-}$. Consequently, the $\mathrm{Chi} @ \mathrm{Fe}_{2} \mathrm{O}_{3}-\mathrm{PVDF}-$ based filtration process is expected to show a promising direction and be developed as a practical method for wastewater treatment.
\end{abstract}

Keywords: composite membrane; filtration; immobilization; water treatment; hexavalent chromium

\section{Introduction}

Environmental pollution caused by leakage of heavy metals is a serious problem worldwide [1,2]. Chromium is a toxic heavy metal that commonly exists in wastewater produced during steel manufacturing, leather tanning, and so on. Particularly, hexavalent chromium $(\mathrm{Cr}(\mathrm{VI}))$ (e.g., $\left.\mathrm{HCrO}_{4}^{-}\right)$is generated in the process of various industrial processes and is 500 times more toxic than trivalent $\mathrm{Cr}(\mathrm{III})$, which is also present in nature [3]. This metal species can also be generated in the chemical decontamination procedure for removal of the oxide layer deposited in the primary system of a nuclear power plant. Moreover, radioactive chromium $\left({ }^{51} \mathrm{Cr}, \mathrm{t}_{1 / 2}=27.7\right.$ days $)$ is found in radioactive wastewater as a result of several nuclear activities, such as radioisotope production and radiochemistry research $[4,5]$. $\mathrm{Cr}(\mathrm{VI})$ is known to cause many human diseases, such as anemia, liver damage, diarrhea, cancer, and kidney damage. The World Health Organization has established $0.05 \mathrm{mg} / \mathrm{L}$ as the maximum admissible concentration of $\mathrm{Cr}(\mathrm{VI})$, and $2 \mathrm{mg} / \mathrm{L}$ of total chromium in drinking water [6-8]. Therefore, an efficient method for desalination of hexavalent chromium from wastewater is necessary.

For years, many methods have been reported for the removal of $\mathrm{Cr}(\mathrm{VI})$, such as electrochemical treatment [9-11], reverse osmosis [12,13], photocatalytic reduction [14], ion 
exchange [15,16], and adsorption [17-21]. Among them, the adsorption method has the advantage of a simple and fast removal process and thus, it has high potential for removing chromium ions from wastewater. Various types of adsorbents have been developed recently. For example, functionalized iron oxide nanoparticles (i.e., $\mathrm{Fe}_{2} \mathrm{O}_{3}$ and $\mathrm{Fe}_{3} \mathrm{O}_{4}$ ) have been widely used for efficient removal of toxic heavy metal ions due to their low toxicity, easy and inexpensive preparation, and large surface area [22-25]. However, their adsorption efficiency is not satisfactory due to the slow adsorption kinetics, and moreover an additional separation process for removal of the adsorbent from the water is required after the desalination procedure is finished. In this study, we developed an adsorbent-embedded polymeric membrane for rapid capture of $\mathrm{Cr}(\mathrm{VI})$ by a filtration process. Compared to previous methods, membrane filtration can be a highly effective technique for removing heavy metal ions from large volumes of water as it does not require an additional process of removing adsorbents and can quickly and effectively remove pollutants from wastewater [26]. The use of a composite membrane, which stably immobilizes adsorbents, minimizes the aggregation of the nanoadsorbent and allows for easy elimination of contaminated solid waste. In addition, membrane filtration is suitable for continuous systems [27,28] and adsorbent-immobilized membranes can be applied in a continuous in-flow system for the efficient treatment of wastewater [29]. Among various polymeric membranes, we selected hydrophilic poly(vinylidene fluoride) (PVDF), a commercially available polymeric membrane, for its advantages, such as thermal stability, chemical resistance, high mechanical strength, and tunable hydrophilicity. Due to these characteristics, it is widely used in various membrane filtration processes $[30,31]$. Chitosan is widely used for water purification because of its properties, such as biodegradability and nontoxicity. It has large numbers of amine functional groups that can chelate the metal ions easily [32].

Previously, we have reported continuous in-flow removal of radioactive wastes in water using an adsorbent-immobilized composite membrane [33,34]. The gold nanoparticle immobilized cellulose acetate membrane showed rapid adsorption capability for radioactive iodide ions within a short duration. In addition, the nanoparticles immobilized to the membrane were highly stable, due to which leaching did not occur even under severe conditions, such as $0.1 \mathrm{M} \mathrm{HCl}, 0.1 \mathrm{M} \mathrm{NaOH}$, and $1.0 \mathrm{M} \mathrm{NaCl}$. Inspired by the previous research, a new composite adsorbent can be fabricated by immobilizing chitosan-coated iron oxide on the hydrophilic poly(vinylidene fluoride) (Chi@ $\mathrm{Fe}_{2} \mathrm{O}_{3}-\mathrm{PVDF}$ ) for rapid, selective, and efficient removal of $\mathrm{Cr}(\mathrm{VI})$. In the present study, the applicability of the composite membrane to $\mathrm{Cr}(\mathrm{VI})$ removal from various real water samples and the performance of the composite membrane in the presence of coexisting ions were investigated.

\section{Materials and Methods}

\subsection{General Methods}

Chitosan-coated iron oxide nanomaterials $\left(\gamma-\mathrm{Fe}_{2} \mathrm{O}_{3}\right.$, average hydrodynamic diameter: $50 \mathrm{~nm}$ ) were purchased from Chemicell (Berlin, Germany). Potassium dichromate $\left(\mathrm{K}_{2} \mathrm{Cr}_{2} \mathrm{O}_{7}\right.$, 99\%) was purchased from Sigma Aldrich (Yongin, Korea). Hydrochloric acid (HCl, 37\%), sodium hydroxide $(\mathrm{NaOH})$, acetic acid $\left(\mathrm{CH}_{3} \mathrm{CO}_{2} \mathrm{H}, 99 \%\right)$, acetone, sulfuric acid $\left(\mathrm{H}_{2} \mathrm{SO}_{4}\right.$, 97\%), and 1,5-diphenylcarbazide (DPC, $\mathrm{C}_{13} \mathrm{H}_{14} \mathrm{~N}_{4} \mathrm{O}, 99 \%$ ) were purchased from Duksan Pure Chemicals Co. Ltd. (Daejeon, Korea). All reagents were of analytical grade and used without further purification. Hydrophilic poly(vinylidene fluoride) membrane (PVDF, pore size $=0.20 \mu \mathrm{m}$, diameter $=47 \mathrm{~mm}$ ) was purchased from Hyundai Micro Co. Ltd. (Daejeon, Korea). The vacuum filtration apparatus was purchased from Phenomenex Inc. (Torrance, CA, USA).

\subsection{Preparation of the Composite Membrane (Chi@Fe $\mathrm{O}_{3}-\mathrm{PVDF}$ )}

Chi@Fe $\mathrm{O}_{3}-\mathrm{PVDF}$ was prepared as described in Figure $\mathrm{S} 1$ with a glass vacuum filter

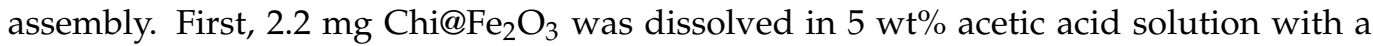
final volume of $100 \mathrm{~mL}$. The hydrophilic PVDF membrane (diameter $=47 \mathrm{~mm}$, pore size $=0.20 \mu \mathrm{m}$ ) was placed between the filter holder fritted glass support and the graduated 
funnel. Chi@ $\mathrm{Fe}_{2} \mathrm{O}_{3}$ nanoparticles $(100 \mathrm{~mL})$ were poured into the graduated funnel and then a vacuum was applied until all the nanoparticles passed through the membrane. Next, a protonation process was conducted to effectively use the amino groups of the Chi@ $\mathrm{Fe}_{2} \mathrm{O}_{3}-\mathrm{PVDF}$ for $\mathrm{Cr}(\mathrm{VI})$ adsorption. The composite membranes were treated with $0.1 \mathrm{M} \mathrm{HCl}$ for $30 \mathrm{~min}$ at $25^{\circ} \mathrm{C}$. After washing the membrane with DI water several times, the prepared $\mathrm{Chi} @ \mathrm{Fe}_{2} \mathrm{O}_{3}-\mathrm{PVDF}$ was kept under ambient conditions until it was applied in the desalinization experiment.

\subsection{Analytical Instruments and Characterization of the Composite Membrane (Chi@Fe $\left.\mathrm{O}_{3}-\mathrm{PVDF}\right)$}

Concentrations of $\mathrm{Cr}(\mathrm{VI})$ in aqueous solutions were measured using quartz cuvettes and a UV-Vis spectrophotometer (UV-1800, Shimadzu, Japan) (Figures S2 and S3). The surface charge of the PVDF membrane and $\mathrm{Chi} @ \mathrm{Fe}_{2} \mathrm{O}_{3}$ were analyzed using the streaming potential method in an Electro-Kinetic analyzer (Anton Paar GmbH, Surpass 3, Seoul, Korea). The elemental composition of the $\mathrm{Chi} @ \mathrm{Fe}_{2} \mathrm{O}_{3}-\mathrm{PVDF}$ was analyzed by scanning electron microscopy with energy-dispersive X-ray (SEM-EDX, SU8220, Hitachi, Japan) analysis with accelerating voltages of up to $30 \mathrm{kV}$. EDX spectra were recorded in area scanning mode by focusing the electron beam onto a region of the sample surface. The amount of iron particles liberated from the composite membrane was measured by an inductively coupled plasma spectrometer (ICP, Optima 7300DV, Perkin Elmer, UK).

\subsection{Adsorbate Preparation}

A stock solution of $\mathrm{Cr}(\mathrm{VI})(500 \mathrm{mg} / \mathrm{L})$ was prepared by the dissolution of the analytical reagent $\mathrm{K}_{2} \mathrm{Cr}_{2} \mathrm{O}_{7}$ in $50 \mathrm{~mL}$ of DI water, and further dilution was conducted to obtain the desired concentrations. The initial $\mathrm{pH}$ adjustment was made using $0.1 \mathrm{M} \mathrm{HCl}$ or $0.1 \mathrm{M}$ $\mathrm{NaOH}$ solutions as required. The $\mathrm{pH}$ was measured using a $\mathrm{pH}$ meter. All the adsorption experiments were performed at solution $\mathrm{pH} 4$, except for the effect of $\mathrm{pH}$, which was performed by varying the $\mathrm{pH}$ from 2 to 10 .

\subsection{Adsorption Experiments}

\subsubsection{Adsorption Experiments Using Batch System}

To investigate the performance of the $\mathrm{Chi} @ \mathrm{Fe}_{2} \mathrm{O}_{3}-\mathrm{PVDF}$ for removal of $\mathrm{Cr}(\mathrm{VI}), \mathrm{K}_{2} \mathrm{Cr}_{2} \mathrm{O}_{7}$ was diluted with $3 \mathrm{~mL}$ DI water at different concentrations $(1,5,10,25,50$, and $100 \mathrm{ppm})$ and poured into Petri dishes (50-mm diameter and 15-mm height). Chi@ $\mathrm{Fe}_{2} \mathrm{O}_{3}-\mathrm{PVDF}$ was immersed in each Petri dish and kept at room temperature under gentle shaking. The solution was sampled $(200 \mu \mathrm{L})$ at different time periods $(1,3,5,10$, and $30 \mathrm{~min})$. The amount of adsorbed $\mathrm{Cr}(\mathrm{VI})$ on the membrane was analyzed by the standard diphenylcarbazide method (540 nm) (0.03 to $1 \mathrm{ppm}$ ) [35] and the direct method (370 nm) (above $1 \mathrm{ppm}$ ) [36] using UV-Vis spectrometry (Figures S2 and S3).

The percentage removal efficiency of $\mathrm{Chi} @ \mathrm{Fe}_{2} \mathrm{O}_{3}-\mathrm{PVDF}$ was determined using Equation (1):

$$
\text { Removal efficiency }(\%)=\frac{\left(C_{0}-C_{e}\right)}{C_{0}} \times 100
$$

where $\mathrm{Q}_{\mathrm{e}}(\mathrm{mg} / \mathrm{g})$, equilibrium adsorption capacity of $\mathrm{Chi} @ \mathrm{Fe}_{2} \mathrm{O}_{3}-\mathrm{PVDF}$, was determined using Equation (2):

$$
\mathrm{Q}_{\mathrm{e}}=\frac{\left(\mathrm{C}_{0}-\mathrm{C}_{\mathrm{e}}\right)}{\mathrm{m}} \times \mathrm{V}
$$

where $\mathrm{Q}_{\mathrm{e}}(\mathrm{mg} / \mathrm{g})$ is the quantity of $\mathrm{Cr}(\mathrm{VI})$ that was adsorbed on the Chi@ $\mathrm{Fe}_{2} \mathrm{O}_{3}-\mathrm{PVDF}$ at equilibrium time. $\mathrm{C}_{0}(\mathrm{mg} / \mathrm{L})$ and $\mathrm{C}_{\mathrm{e}}(\mathrm{mg} / \mathrm{L})$ represent the initial and final concentration of $\mathrm{Cr}(\mathrm{VI})$ in the aqueous solution at time $\mathrm{t}, \mathrm{V}(\mathrm{L})$ is the volume of the $\mathrm{Cr}(\mathrm{VI})$ solution, and $\mathrm{m}$ (g) represents the mass of the adsorbents (Chi@ $\mathrm{Fe}_{2} \mathrm{O}_{3}, 2.2 \mathrm{mg}$ ). 


\subsubsection{Adsorption Experiments Using Continuous-Flow System}

A stock solution of $\mathrm{K}_{2} \mathrm{Cr}_{2} \mathrm{O}_{7}(500 \mathrm{mg} / \mathrm{L})$ was diluted with pure water to obtain various concentrations $(0.5,1,2.5,5$, and $10 \mathrm{ppm})$ of $\mathrm{Cr}(\mathrm{VI})$ solution. Chi@ $\mathrm{Fe}_{2} \mathrm{O}_{3}-\mathrm{PVDF}$ was placed between the filter holder fritted glass support and the graduated funnel. Next, the $\mathrm{Cr}(\mathrm{VI})$ solution was poured into the graduated funnel and a vacuum was applied until the entire solution was passed through the $\mathrm{Chi} @ \mathrm{Fe}_{2} \mathrm{O}_{3}-\mathrm{PVDF}$. The concentration of adsorbed $\mathrm{Cr}(\mathrm{VI})$ on the membrane was analyzed using UV-Vis spectrometry.

\subsubsection{Adsorption Isotherms}

The adsorption isotherm was determined using the $\mathrm{Cr}(\mathrm{VI})$ solution at $25{ }^{\circ} \mathrm{C}$. Briefly, Chi@ $\mathrm{Fe}_{2} \mathrm{O}_{3}-\mathrm{PVDF}$ was treated with $3 \mathrm{~mL}$ (batch system) or $50 \mathrm{~mL}$ (continuous-flow system) $\mathrm{Cr}(\mathrm{VI})$ at different initial concentrations (1-100 ppm in the batch system, $0.5-10 \mathrm{ppm}$ in the continuous-flow system). The final concentration of $\mathrm{Cr}(\mathrm{VI})$ after the adsorption process was measured via UV-Vis spectroscopy. The Langmuir and Freundlich isotherm models were applied to describe the equilibrium adsorption using Equations (3) and (4), respectively:

$$
\begin{aligned}
& \text { Langmuir equation: } \frac{\mathrm{C}_{\mathrm{e}}}{\mathrm{Q}_{\mathrm{e}}}=\frac{\mathrm{C}_{\mathrm{e}}}{\mathrm{Q}_{\max }}+\frac{1}{\mathrm{Q}_{\max } \mathrm{K}_{\mathrm{L}}} \\
& \text { Freundlich equation : } \ln \mathrm{Q}_{\mathrm{e}}=\ln \mathrm{K}_{\mathrm{F}}+\frac{1}{\mathrm{n}} \ln \mathrm{C}_{\mathrm{e}}
\end{aligned}
$$

where $Q_{\max }(\mathrm{mg} / \mathrm{g})$ is the maximum adsorption capacity of the adsorbents $\left(\mathrm{Chi} @ \mathrm{Fe}_{2} \mathrm{O}_{3}\right)$. $\mathrm{K}_{\mathrm{L}}$ and $\mathrm{K}_{\mathrm{F}}$ are the Langmuir and Freundlich adsorption constants, respectively.

\subsubsection{Adsorption Kinetics}

The adsorption kinetics of $\mathrm{Cr}(\mathrm{VI})$ were determined using 25 ppm of $\mathrm{Cr}(\mathrm{VI})$ solution at room temperature. Briefly, $3 \mathrm{~mL} \mathrm{Cr}(\mathrm{VI})(25 \mu \mathrm{M})$ solution was shaken with $\mathrm{Chi}_{2} \mathrm{Fe}_{2} \mathrm{O}_{3}-$ PVDF. At different time periods $(1,3,5,10,30$, and $60 \mathrm{~min})$, the $\mathrm{Cr}(\mathrm{VI})$ solution $(200 \mu \mathrm{L})$ was collected and the concentration of $\mathrm{Cr}(\mathrm{VI})$ was determined via UV-Vis spectroscopy by measuring the absorbance variation at the maximum wavelength. The adsorption capacity was fitted into the pseudo-first-order and pseudo-second-order kinetics equations with respect to time, as expressed in Equations (5) and (6), respectively:

$$
\begin{gathered}
\text { Pseudo-first-order kinetic model : } \ln \left(\mathrm{Q}_{\mathrm{e}}-\mathrm{Q}_{\mathrm{t}}\right)=\ln \mathrm{Q}_{\mathrm{e}}-\frac{\mathrm{k}_{1} \mathrm{t}}{2.303} \\
\text { Pseudo-second-order kinetic model : } \frac{\mathrm{t}}{\mathrm{Q}_{\mathrm{t}}}=\frac{1}{\mathrm{k}_{2} \mathrm{Q}_{\mathrm{e}}^{2}}+\frac{\mathrm{t}}{\mathrm{Q}_{\mathrm{e}}}
\end{gathered}
$$

where $Q_{e}$ and $Q_{t}$ are the quantities of $\mathrm{Cr}(\mathrm{VI})(\mathrm{mg} / \mathrm{g})$ at equilibrium and time $\mathrm{t}$, respectively. $\mathrm{k}_{1}\left(\mathrm{~min}^{-1}\right)$ and $\mathrm{k}_{2}\left(\mathrm{~g} \mathrm{mg}^{-1} \mathrm{~min}^{-1}\right)$ are the pseudo-first-order and pseudo-second-order adsorption rate constants, respectively.

\section{Results and Discussion}

\subsection{Characterization of Nanocomposite Membrane}

The main strategy for desalination of Cr(IV) by using a nanocomposite membrane and filtration system was illustrated in Figure 1. The preparation of the nanoadsorbentembedded polymeric membrane(Chi@ $\left.\mathrm{Fe}_{2} \mathrm{O}_{3}-\mathrm{PVDF}\right)$ is shown in Figure S1. The immobilization of chitosan-coated iron oxide nanoparticles was conducted using commercially available hydrophilic PVDF membrane. Using a vacuum filtration system, $2.2 \mathrm{mg}$ chitosancoated iron oxide nanoparticles were stably immobilized on the membrane, which exhibited a homogeneous and yellow-brown color. The surface morphology was characterized using scanning electron microscopy (SEM) and energy-dispersive X-ray analysis (EDX). In Figure 2, the chitosan-coated iron oxide nanoparticles were well distributed on the nanofibers of the PVDF membrane. To confirm whether the nanoparticles were stably 
immobilized on the membrane and could be used for chromium removal, ICP analysis was performed under various conditions (e.g., deionized water; $\mathrm{Cr}(\mathrm{VI}) 25$ ppm (pH 4, 6, and 10); $0.1 \mathrm{M} \mathrm{HCl} ; 0.1 \mathrm{M} \mathrm{NaOH}$; and $0.1 \mathrm{M} \mathrm{NaCl}$ ) after immersing the membrane for $1 \mathrm{~h}$. As shown in Table 1, $0.371 \%$ of iron oxide nanoparticles were released from the membrane under $0.1 \mathrm{M} \mathrm{HCl}$ conditions. In addition, it was observed that $0.033 \%$ and $0.046 \%$ nanoparticles were lost in the 25 ppm chromium solutions under pH 7 and pH 10, respectively. Not only are these very small amounts, but also their loss is not expected to have a significant impact because the filtration process for removing chromium ions proceeds within about $20 \mathrm{~s}$. These results can be explained in two ways. First, the stability of composite nanomaterials can be explained by the electrostatic interaction between the chitosan-coated iron oxide nanoparticles (zeta potential $=+21.2 \mathrm{mV}$ ) and the PVDF membrane (zeta potential $=-18.9 \mathrm{mV}$ ). At neutral $\mathrm{pH}$, the positively charged amine functional group of chitosan and negatively charged membrane have strong electrostatic interactions. Second, dipole interactions between electron-poor methylene $\left(\mathrm{CH}_{2}\right)$ groups in the PVDF chain and hydroxy groups on the surface of the iron oxide may contribute to stability. Figure 3 shows the Fourier-transform infrared (FT-IR) spectra of PVDF, Chi@ $\mathrm{Fe}_{2} \mathrm{O}_{3} \mathrm{NPs}$, and Chi@ $\mathrm{Fe}_{2} \mathrm{O}_{3}-\mathrm{PVDF}$. In the spectra of Chi@ $\mathrm{Fe}_{2} \mathrm{O}_{3}-\mathrm{PVDF}$, the bands at 3395, 1646, and $548 \mathrm{~cm}^{-1}$ are characteristics of the stretching vibrations of $-\mathrm{OH}, \mathrm{N}-\mathrm{H}$ bending of $\mathrm{NH}_{2}$, and $\mathrm{Fe}-\mathrm{O}$ stretching vibration of $\mathrm{Fe}_{2} \mathrm{O}_{3}$ in $\mathrm{Chi} @ \mathrm{Fe}_{2} \mathrm{O}_{3} \mathrm{NPs}$, respectively. Additionally, the bands at 1179 , and $1067 \mathrm{~cm}^{-1}$ indicate the stretching vibration of $-\mathrm{CF}_{2}$ and the stretching band of $\mathrm{C}-\mathrm{F}$ in PVDF. These results show that the composite membrane is fabricated successfully using PVDF and Chi@ $\mathrm{Fe}_{2} \mathrm{O}_{3} \mathrm{NPs}$.

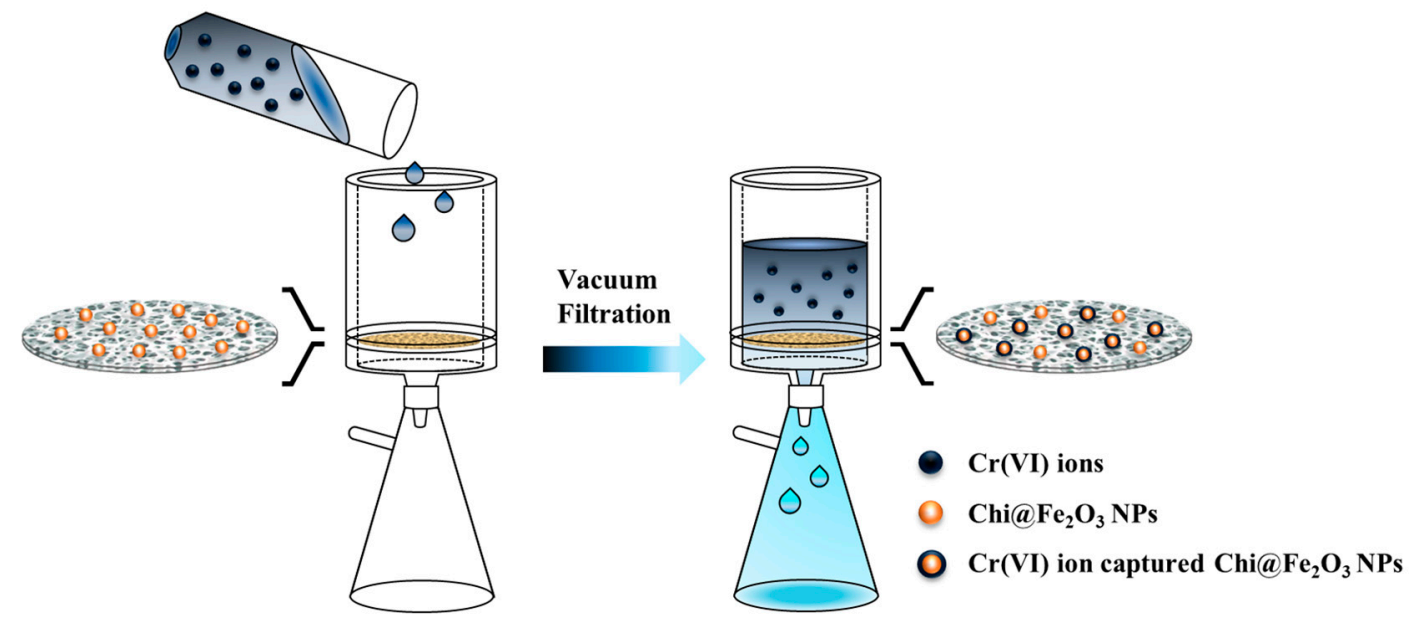

Figure 1. Schematic illustration of the desalinization procedure using a chitosan-coated iron oxide nanocomposite poly(vinylidene fluoride) membrane (Chi@ $\left.\mathrm{Fe}_{2} \mathrm{O}_{3}-\mathrm{PVDF}\right)$.

Table 1. Quantification of detached iron oxide nanoparticles under acidic, basic, and high-salt conditions after $1 \mathrm{~h}$, analyzed by inductively coupled plasma spectrometer.

\begin{tabular}{|c|c|c|}
\hline \multirow{2}{*}{ Solvent } & \multicolumn{2}{|c|}{$\mathrm{Chi} @ \mathrm{Fe}_{2} \mathrm{O}_{3}-\mathrm{PVDF}$} \\
\hline & ppm $(\mathrm{mg} / \mathrm{L})$ & $\mathbf{W t} \%$ \\
\hline Deionized water & N.D. & - \\
\hline $\mathrm{Cr}(\mathrm{VI}) 25$ ppm (pH 4) & N.D. & - \\
\hline $\mathrm{Cr}(\mathrm{VI}) 25$ ppm (pH 7) & 0.131 & $0.033 \%$ \\
\hline $\mathrm{Cr}(\mathrm{VI}) 25 \mathrm{ppm}(\mathrm{pH} 10)$ & 0.182 & $0.046 \%$ \\
\hline $0.1 \mathrm{M} \mathrm{HCl}$ & 1.469 & $0.371 \%$ \\
\hline $0.1 \mathrm{M} \mathrm{NaOH}$ & N.D. & - \\
\hline $0.1 \mathrm{M} \mathrm{NaCl}$ & N.D. & - \\
\hline
\end{tabular}


(a)

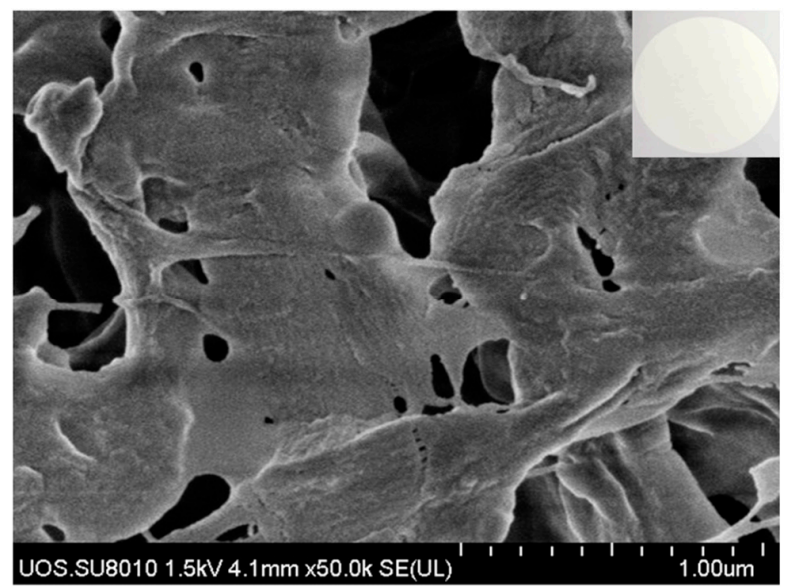

(b)

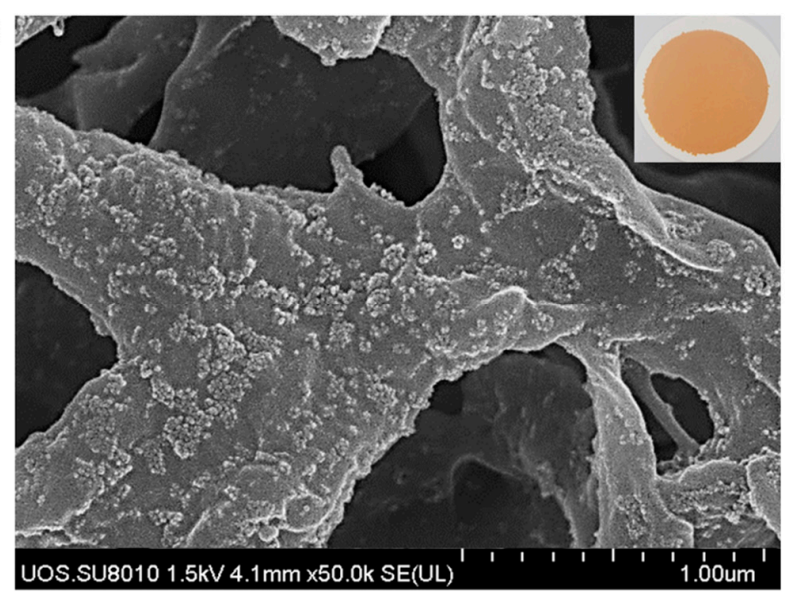

Figure 2. Scanning electron microscope images of (a) poly(vinylidene fluoride) (PVDF); (b) Chi@ $\mathrm{Fe}_{2} \mathrm{O}_{3}-\mathrm{PVDF}$. White dots indicate $\mathrm{Chi} @ \mathrm{Fe}_{2} \mathrm{O}_{3}$ NPs deposited on the membrane.

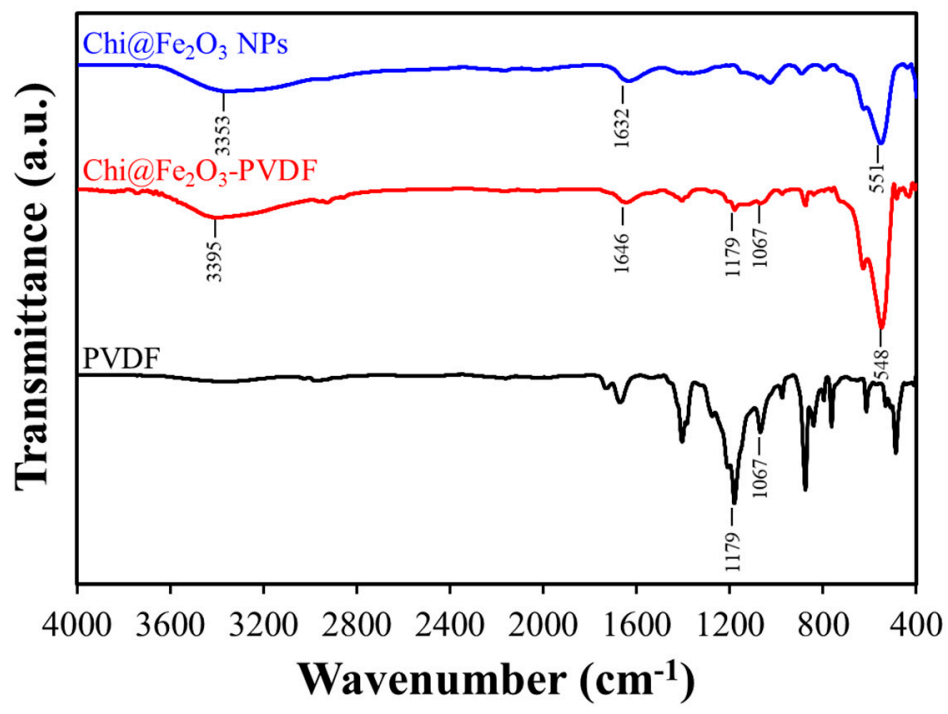

Figure 3. Fourier-transform infrared spectra (FT-IR) of poly(vinylidene fluoride) (PVDF) (black), Chi@ $\mathrm{Fe}_{2} \mathrm{O}_{3} \mathrm{NPs}$ (blue), and Chi@ $\mathrm{Fe}_{2} \mathrm{O}_{3}-\mathrm{PVDF}$ (red).

Elemental analysis of the $\mathrm{Chi} @ \mathrm{Fe}_{2} \mathrm{O}_{3}-\mathrm{PVDF}$ showed an iron atom peak, representing the incorporation of PVDF membrane and the nanoadsorbent (Figure 4a). Carbon, oxygen, and fluorine atoms were observed and attributed to the backbone structure of the PVDF membrane. These results demonstrate that $\mathrm{Chi} @ \mathrm{Fe}_{2} \mathrm{O}_{3}-\mathrm{PVDF}$ was successfully prepared.

\subsection{Effect of Solution $p H$}

$\mathrm{pH}$ is an important factor in the adsorption process of $\mathrm{Chi} @ \mathrm{Fe}_{2} \mathrm{O}_{3}-\mathrm{PVDF}$ because the amino groups of chitosan can be protonated at lower $\mathrm{pH}$, which affects the surface charge of $\mathrm{Chi} @ \mathrm{Fe}_{2} \mathrm{O}_{3}-\mathrm{PVDF}$. We first investigated the removal capability of the composite membrane under some different conditions. As shown in Figure 5a, $\mathrm{Chi} @ \mathrm{Fe}_{2} \mathrm{O}_{3}-\mathrm{PVDF}$ pretreated with an acidic solution had the highest removal efficiency, which is related to the positively charged surface caused by the amino group of protonated chitosan. In addition, the surface charge of nanoadsorbents depends on the $\mathrm{pH}$ of solvent. The surface charge becomes neutral at $\mathrm{pH} 5.8$ for iron oxide; further lowering the $\mathrm{pH}$ will render the adsorbent surface rich in positive charges and $\mathrm{Cr}(\mathrm{VI})$, resulting in better adsorption $[37,38]$. On the other hand, non-treated composite membrane and bare PVDF exhibited much lower removal efficiencies than that of pretreated Chi@ $\mathrm{Fe}_{2} \mathrm{O}_{3}-\mathrm{PVDF}$ (Figure 5a). Next, 
the removal of $\mathrm{Cr}(\mathrm{VI})$ was evaluated by immerging the composite membrane, which was pretreated under acidic condition, in $\mathrm{Cr}(\mathrm{VI})$ solutions in varied $\mathrm{pH}$. Figure $5 \mathrm{~b}$ shows the result of testing the removal efficiency by varying the $\mathrm{pH}$ of the $\mathrm{Cr}(\mathrm{VI})$ solution. $\mathrm{Cr}(\mathrm{VI})$ removal efficiency gradually increased as the $\mathrm{pH}$ decreased from 10 to 4 and reached its peak at $\mathrm{pH} 4(90.45 \%)$. However, at $\mathrm{pH} 2$, the removal efficiency of $\mathrm{Cr}(\mathrm{VI})$ decreased. This is related to the conversion of the ionic form of $\mathrm{Cr}(\mathrm{VI})$ with varying $\mathrm{pH}$ value. $\mathrm{Cr}(\mathrm{VI})$ anions have different ionic forms depending on the $\mathrm{pH}$, where $\mathrm{CrO}_{4}{ }^{2-}$ is dominant at $\mathrm{pH} 6$ or higher, and $\mathrm{HCrO}_{4}{ }^{-}$and $\mathrm{Cr}_{2} \mathrm{O}_{7}{ }^{2-}$ are the main forms at $\mathrm{pH} 2-6 . \mathrm{H}_{2} \mathrm{CrO}_{4}$ is predominant at more acidic $\mathrm{pH}$. In addition, as the $\mathrm{pH}$ value of the iron oxide increases, a negative charge is generated on the surface of the adsorbents and thus, the electrostatic repulsion between the iron oxides and the $\mathrm{Cr}(\mathrm{VI})$ anion increases significantly. Therefore, $\mathrm{Chi} @ \mathrm{Fe}_{2} \mathrm{O}_{3}-\mathrm{PVDF}$ has the highest removal efficiency at $\mathrm{pH} 4$ for $\mathrm{Cr}(\mathrm{VI})$ by electrostatic interactions among chitosan, iron oxide surfaces, and $\mathrm{Cr}(\mathrm{VI})$.

(a)

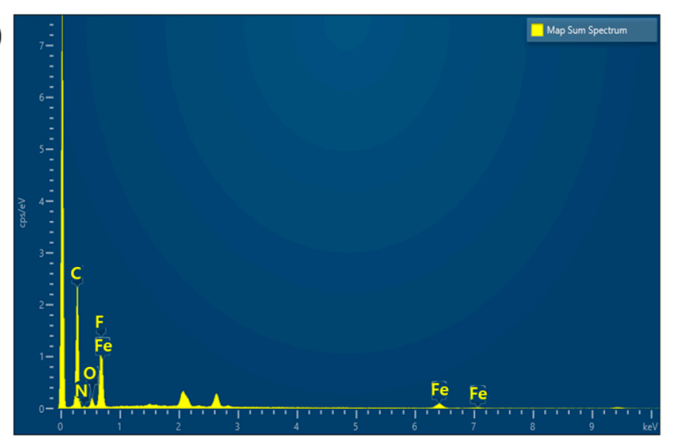

(b)

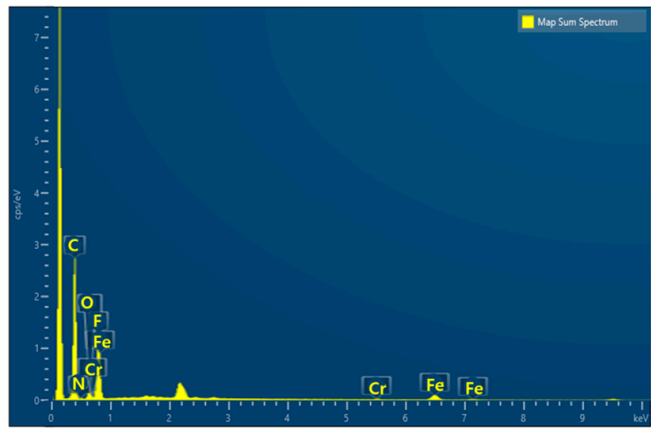

\begin{tabular}{ccc}
\hline Element & $\mathbf{W t} \%$ & Atomic $\%$ \\
\hline $\mathrm{C}$ & 56.00 & 68.41 \\
$\mathrm{O}$ & 6.17 & 5.66 \\
$\mathrm{~F}$ & 31.39 & 24.24 \\
$\mathrm{Fe}$ & 6.44 & 1.69 \\
\hline Total & 100.00 & 100.00 \\
\hline Element & $\mathbf{W t} \%$ & $\mathbf{A t o m i c} \%$ \\
\hline $\mathrm{C}$ & 59.21 & 71.35 \\
$\mathrm{O}$ & 6.27 & 5.67 \\
$\mathrm{~F}$ & 27.90 & 21.25 \\
$\mathrm{Cr}$ & 0.42 & 0.12 \\
$\mathrm{Fe}$ & 6.21 & 1.61 \\
\hline Total & 100.00 & 100.00 \\
\hline
\end{tabular}

Figure 4. Energy-dispersive X-ray spectroscopy analysis of (a) $\mathrm{Chi}_{0} \mathrm{Fe}_{2} \mathrm{O}_{3}-\mathrm{PVDF}$ and (b) $\mathrm{Cr}(\mathrm{VI})$ captured Chi@ $\mathrm{Fe}_{2} \mathrm{O}_{3}-\mathrm{PVDF}$.

(a)

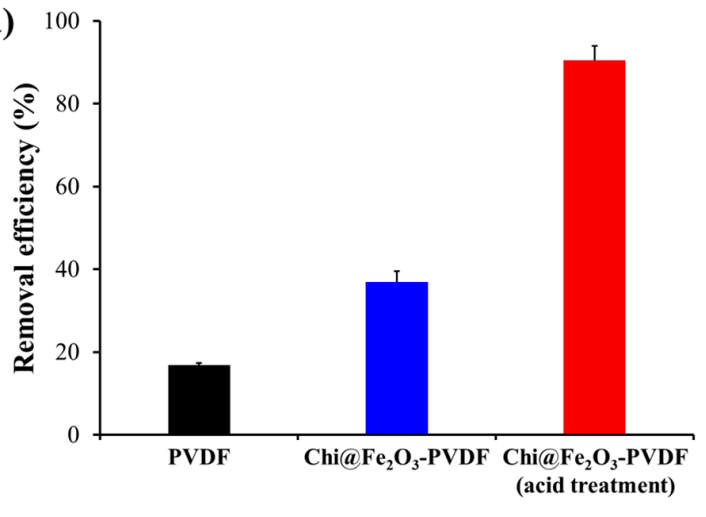

(b)

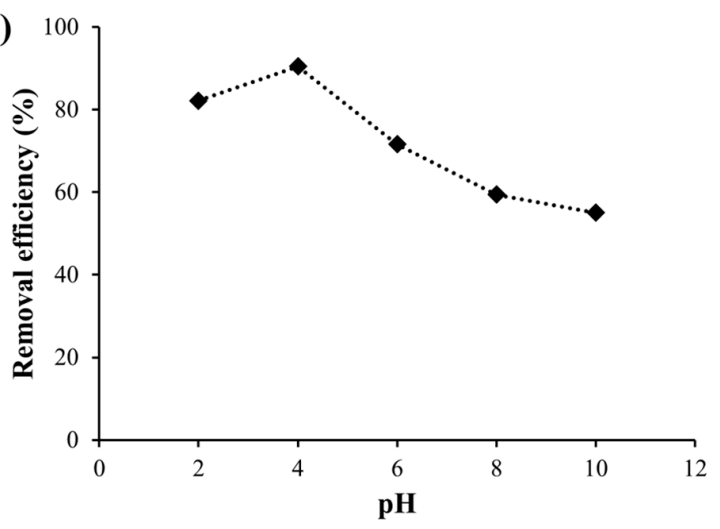

Figure 5. (a) Comparison of removal efficiency of PVDF, Chi@ $\mathrm{Fe}_{2} \mathrm{O}_{3}-\mathrm{PVDF}$, and Chi@ $\mathrm{Fe}_{2} \mathrm{O}_{3}-\mathrm{PVDF}$ after acid treatment; (b) Effect of $\mathrm{pH}$ on the adsorption of $\mathrm{Cr}(\mathrm{VI})$ using $\mathrm{Chi} @ \mathrm{Fe}_{2} \mathrm{O}_{3}-\mathrm{PVDF}$. 


\subsection{Adsorption of $\mathrm{Cr}(\mathrm{VI})$ Using $\mathrm{Chi} @ \mathrm{Fe}_{2} \mathrm{O}_{3}-\mathrm{PVDF}$ \\ 3.3.1. Batch System}

To investigate the desalinization capability of the $\mathrm{Chi} @ \mathrm{Fe}_{2} \mathrm{O}_{3}-\mathrm{PVDF}$, it was immersed in aqueous solutions containing $\mathrm{Cr}(\mathrm{VI})$ at $\mathrm{pH} 4$ to measure the typical desalinization performance of Chi@ $\mathrm{Fe}_{2} \mathrm{O}_{3}-\mathrm{PVDF}$ for $\mathrm{Cr}(\mathrm{VI})$ with $30 \mathrm{~min}$ by batch system. The removal capacity $\left(\mathrm{Q}_{\mathrm{e}}\right)$ of the $\mathrm{Chi} @ \mathrm{Fe}_{2} \mathrm{O}_{3}-\mathrm{PVDF}$ increased with an increase in the initial concentration of $\mathrm{Cr}(\mathrm{VI})$. The adsorption of $\mathrm{Cr}(\mathrm{VI})$ on the surface of $\mathrm{Chi} @ \mathrm{Fe}_{2} \mathrm{O}_{3}-\mathrm{PVDF}$ was confirmed by the EDX analysis that shows a characteristic $\mathrm{Cr}$ peak (Figure $4 \mathrm{~b}$ ). The elemental mapping patterns of $\mathrm{Chi} @ \mathrm{Fe}_{2} \mathrm{O}_{3}-\mathrm{PVDF}$ showed the presence of iron with chromium, thus confirming capture of the target metal species on the composite membrane (Figure 6). The linear fitting of the observed data based on the Langmuir and Freundlich isotherm models (Figure 7a,b) revealed that the performance of $\mathrm{Chi} @ \mathrm{Fe}_{2} \mathrm{O}_{3}$-PVDF was better fitted by the Langmuir equation with a correlation factor $\left(R^{2}\right)$ of 0.9877 . These results indicated the monolayer adsorption mechanism, and the observed maximum adsorption capacity $\left(\mathrm{Q}_{\max }\right)$ obtained using Equation (3) was $14.451 \mathrm{mg} / \mathrm{g}$. The corresponding parameters for these models are summarized in Table 2.
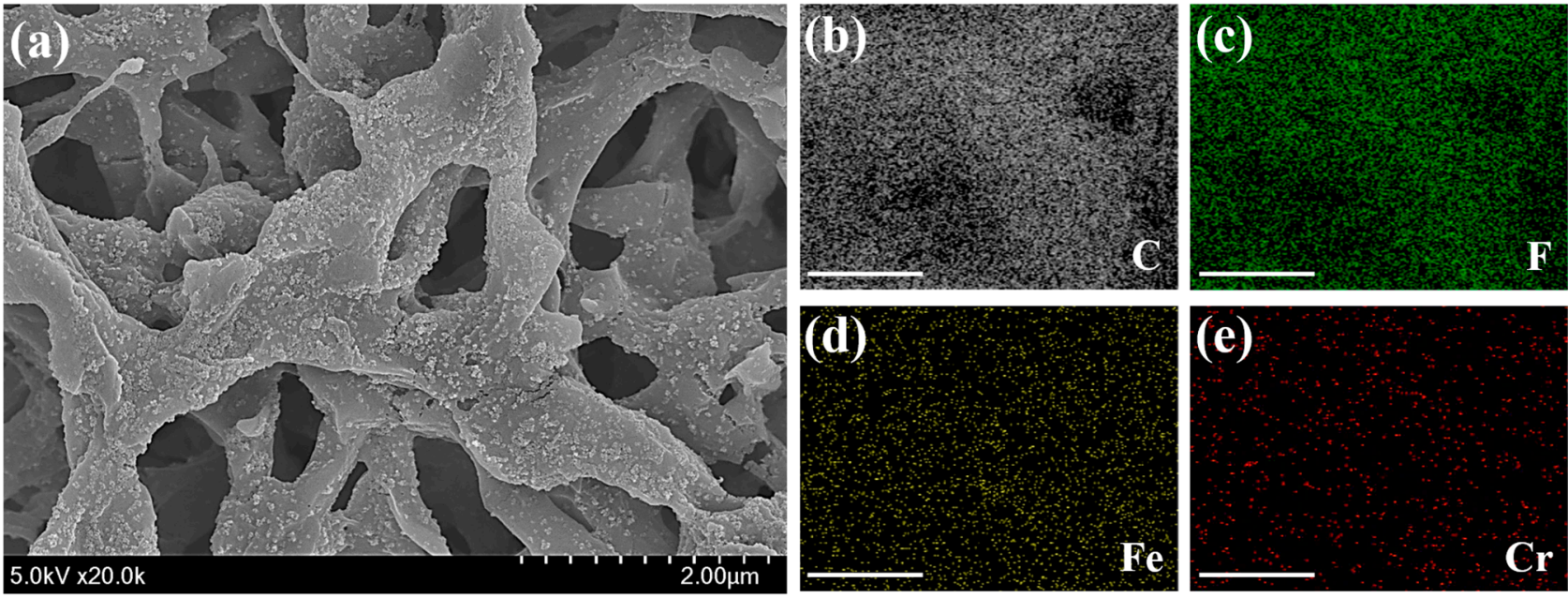

Figure 6. (a) Scanning electron microscope image of $\mathrm{Cr}(\mathrm{VI})$ captured $\mathrm{Chi} @ \mathrm{Fe}_{2} \mathrm{O}_{3}-\mathrm{PVDF}$; (b-e) Energydispersive X-ray spectroscopy elemental mapping patterns of $\mathrm{Cr}(\mathrm{VI})$ captured $\mathrm{Chi} @ \mathrm{Fe}_{2} \mathrm{O}_{3}-\mathrm{PVDF}$ (scale bar $=1 \mu \mathrm{m})$.

Table 2. Adsorption isotherms and kinetic parameters of $\mathrm{Cr}(\mathrm{VI})$ onto $\mathrm{Chi} @ \mathrm{Fe}_{2} \mathrm{O}_{3}-\mathrm{PVDF}$.

\begin{tabular}{|c|c|c|c|c|c|c|c|}
\hline \multirow{2}{*}{ System } & \multicolumn{2}{|c|}{ Langmuir Constants } & \multicolumn{5}{|c|}{ Freundlich Constants } \\
\hline & $\mathrm{K}_{\mathrm{L}}\left(\mathrm{L} \mathrm{mg}^{-1}\right)$ & $Q_{\max }\left(\mathrm{mg} \mathrm{g}^{-1}\right)$ & $\mathbf{R}^{2}$ & $\mathrm{~K}_{\mathrm{F}}(\mathrm{mg}$ & -1) $\left(\mathrm{L} \mathrm{mg}^{-1}\right)^{1 / n}$ & n & $\mathbf{R}^{2}$ \\
\hline \multirow{2}{*}{$\begin{array}{c}\text { Batch } \\
\text { Continuous- } \\
\text { Flow }\end{array}$} & 1.640 & 14.451 & 0.998 & & 7.036 & 3.670 & 0.571 \\
\hline & 18.658 & 14.104 & 0.995 & & 11.454 & 6.337 & 0.527 \\
\hline \multirow{2}{*}{ System } & $\begin{array}{l}\text { Experimental } \\
\text { value }\end{array}$ & \multicolumn{3}{|c|}{ Pseudo-first order } & \multicolumn{3}{|c|}{ Pseudo-second order } \\
\hline & $\begin{array}{c}\mathrm{Q}_{\mathrm{e}, \exp } \\
\left(\mathrm{mg} \mathrm{g}^{-1}\right)\end{array}$ & $\mathrm{k}_{1}\left(\min ^{-1}\right)$ & $\begin{array}{c}\mathrm{Q}_{\mathrm{e}, \mathrm{cal}} \\
\left(\mathrm{mg} \mathrm{g}^{-1}\right)\end{array}$ & $\mathrm{R}^{2}$ & $\left(\mathrm{~g} \mathrm{mg}^{-1} \min ^{-1}\right)$ & $\begin{array}{c}\mathrm{Q}_{\mathrm{e}, \mathrm{cal}} \\
\left(\mathrm{mg} \mathrm{g}^{-1}\right)\end{array}$ & $\mathrm{R}^{2}$ \\
\hline Batch & 28.737 & 0.011 & 9.206 & 0.3748 & 0.634 & 21.231 & 0.9994 \\
\hline
\end{tabular}


(a)

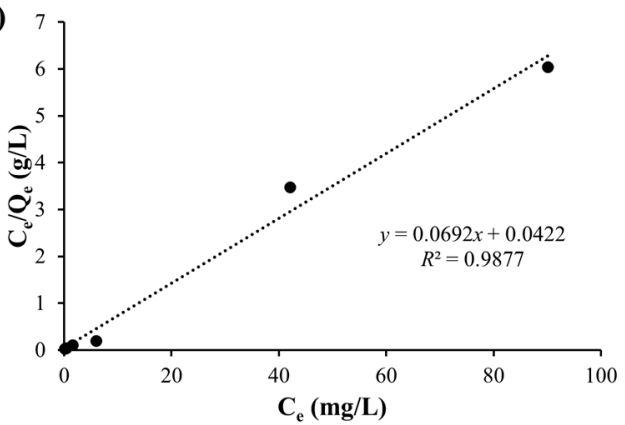

(c)

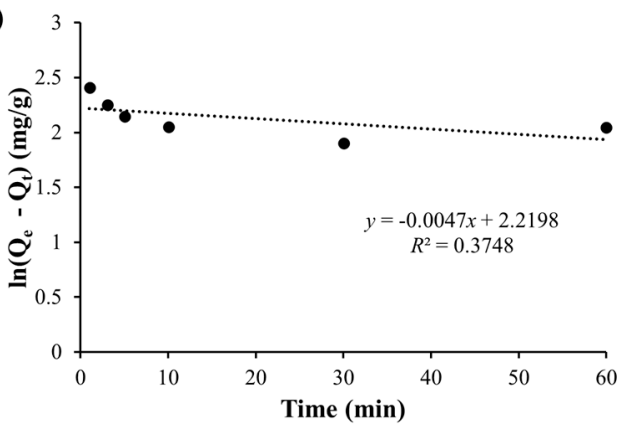

(b)

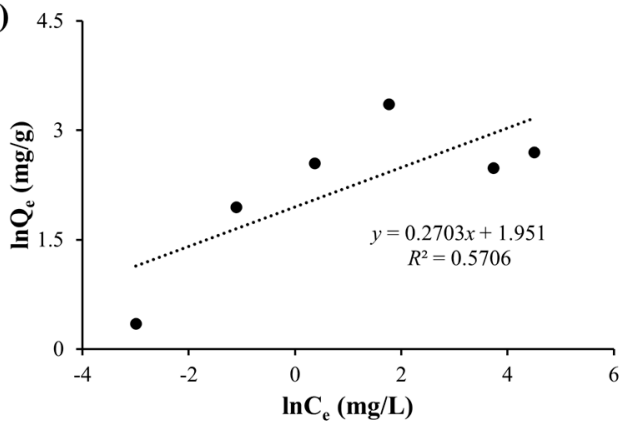

(d)

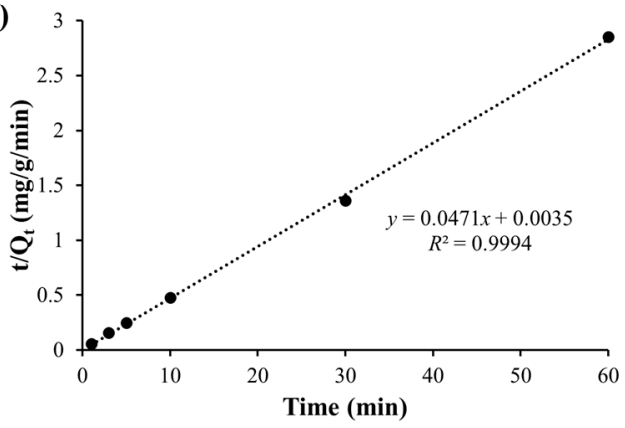

Figure 7. The adsorption isotherms of $\mathrm{Cr}(\mathrm{VI})$ fitted on the basis of (a) the Langmuir model; (b) the Freundlich model; (c) the pseudo-first-order adsorption kinetic; and (d) the pseudo-second-order adsorption kinetic.

The kinetic parameters of batch adsorption are analyzed to evaluate the adsorbent. The removal efficiency of $\mathrm{Cr}(\mathrm{VI})$ was determined as a function of time (1-60 $\mathrm{min}$ ) to determine the optimum time for the desalinization experiments. The adsorption of $\mathrm{Cr}(\mathrm{VI})$ was rapid in the initial $10 \mathrm{~min}$, and gradually became slower, and finally reached the equilibrium after $30 \mathrm{~min}$. The kinetic results of the pseudo-first-order and pseudo-second-order kinetic models are shown in Figure 7c,d. Based on the calculated kinetic parameters, the pseudosecond-order kinetic model fitted better with the kinetic results, which exhibited an $\mathrm{R}^{2}$ value for the pseudo-second-order kinetic model that is approximately 1 (0.9994) and higher than that of the pseudo-first-order kinetic model (0.3748). In addition, the theoretical $\mathrm{Q}_{\max }$ for $\mathrm{Cr}$ (VI) obtained from the pseudo-second-order kinetic model is closer to the experimental $\mathrm{Q}_{\max }$ value. These results indicate that the adsorption behavior is well described by the pseudo-second-order kinetics, suggesting that the rate-limiting step is surface adsorption and involves chemisorption mechanism.

\subsubsection{Continuous In-Flow System}

To study the adsorption behavior of $\mathrm{Chi} @ \mathrm{Fe}_{2} \mathrm{O}_{3}-\mathrm{PVDF}$ for $\mathrm{Cr}(\mathrm{VI})$ in the continuous in-flow system, the data tested in the vacuum filtration system were fitted to the Langmuir model and the Freundlich model. As shown in Figure S4, the linear fitting of the observed data based on the Langmuir and Freundlich isotherm models revealed that $\mathrm{Chi}_{0} \mathrm{Fe}_{2} \mathrm{O}_{3}-$ PVDF was better estimated by the Langmuir model, with the $\mathrm{R}^{2}$ value of 0.995 . In addition, the maximum adsorption capacity of $\mathrm{Chi@Fe} \mathrm{O}_{3}-\mathrm{PVDF}$ in the continuous in-flow system was confirmed to be $14.104 \mathrm{mg} / \mathrm{g}$ by the Langmuir model (Figure 8). 


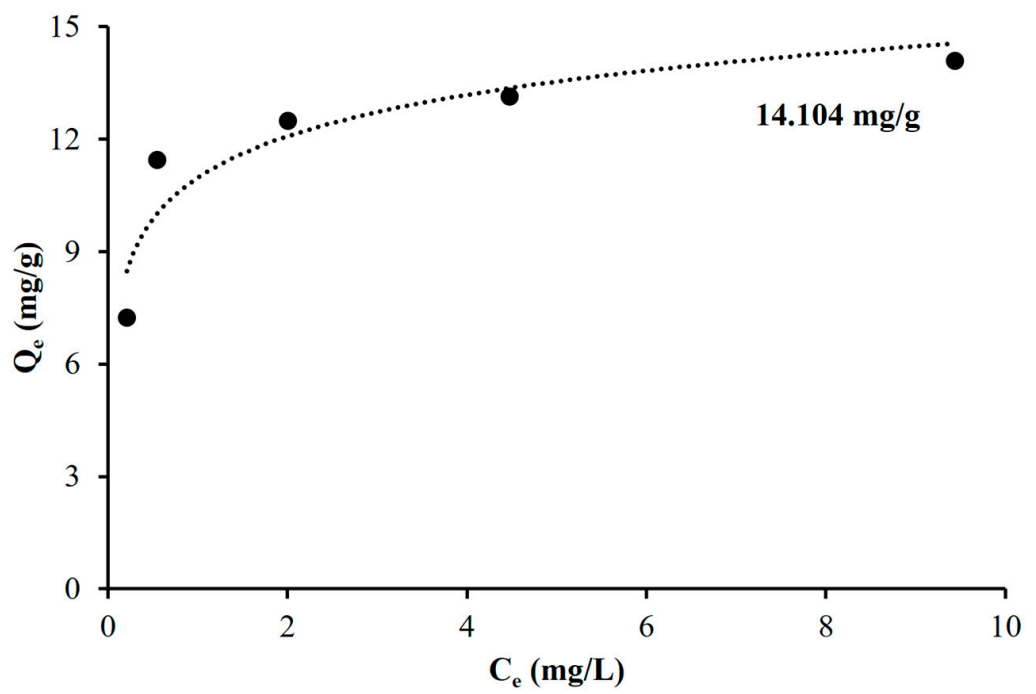

Figure 8. Isotherm data for the removal of $\mathrm{Cr}(\mathrm{VI})$ using $\mathrm{Chi} @ \mathrm{Fe}_{2} \mathrm{O}_{3}-\mathrm{PVDF}$ in the continuous inflow system.

\subsection{Effect of Coexisting Ions on Removal Efficiency in Real Water Samples}

Chromium in actual environmental water generally exists with various types of ions. Therefore, to measure the effect of coexisting ions on chromium removal, experiments were conducted in the presence of four types of ions, i.e., $\mathrm{Cl}^{-}, \mathrm{NO}_{3}{ }^{-}, \mathrm{SO}_{4}{ }^{2-}$, and $\mathrm{PO}_{4}{ }^{3-}$ (for $1 \mathrm{ppm}$ and $10 \mathrm{ppm}$ concentrations). As shown in Figure 9a, the removal efficiency was slightly hindered by the presence of anionic species; however, except for the phosphate ions, Chi@ $\mathrm{Fe}_{2} \mathrm{O}_{3}-\mathrm{PVDF}$ still had approximately $80 \%$ removal efficiency in 1 ppm of coexisting ion. This is because all anions have electrostatic interactions with the amino groups in protonated chitosan. However, although $\mathrm{Cl}^{-}, \mathrm{NO}_{3}{ }^{-}$, and $\mathrm{SO}_{4}{ }^{2-}$ ions exhibit weaker adsorption mechanisms than $\mathrm{Cr}(\mathrm{VI}), \mathrm{PO}_{4}{ }^{3-}$ is an anchoring group and has an affinity with iron oxide; thus, its effect on the removal efficiency is more dramatic $[39,40]$. In addition, as the concentration of coexisting ions increased to $10 \mathrm{ppm}$, the competitive effect of the coexisting ions on $\mathrm{Cr}(\mathrm{VI})$ slightly increased. Further, the desalinization process was applied to real water samples such as tap water, drinking water, and river water. As shown in Figure $9 b$, the removal efficiency was slightly decreased compared to that of the control (solution in deionized water), but there was no noticeable difference. There are several ions in the actual water samples that compete with $\mathrm{Cr}(\mathrm{VI})$; however, in general, there was no significant change in adsorption efficiency for the various types of water samples.
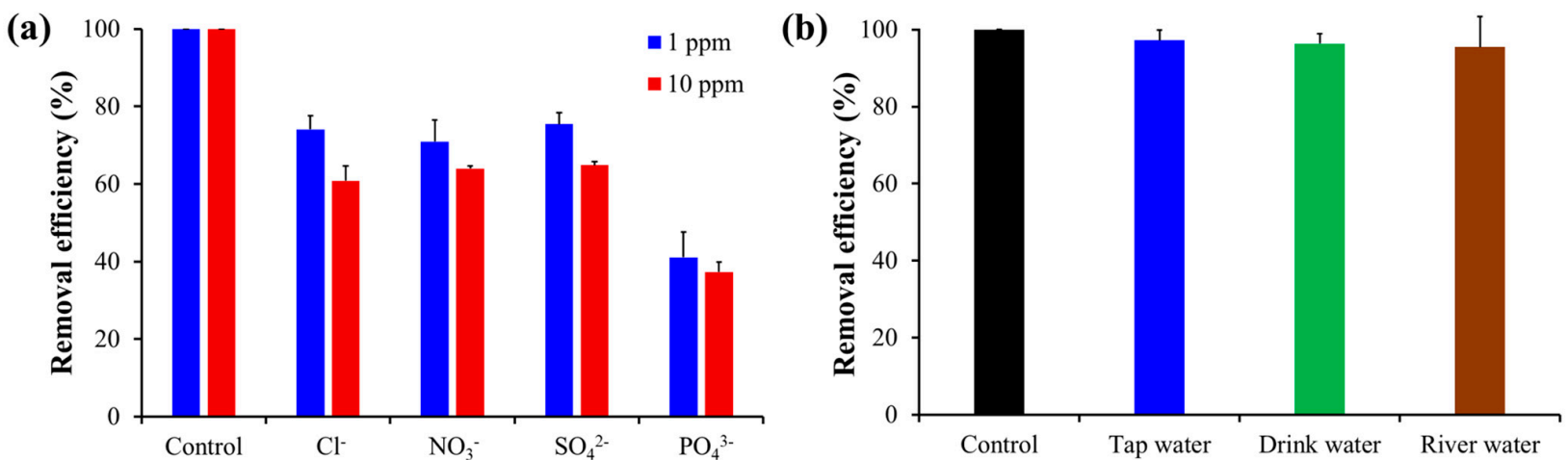

Figure 9. (a) Effect of coexisting ions on the removal of $\mathrm{Cr}(\mathrm{VI})$ using Chi@ $\mathrm{Fe}_{2} \mathrm{O}_{3}-\mathrm{PVDF}$ with a volume of $50 \mathrm{~mL}$, $\mathrm{pH}$ value of 4 , and $\mathrm{Cr}(\mathrm{VI})$ concentration of $1 \mathrm{ppm}$; (b) Real water experiments for the removal of $\mathrm{Cr}(\mathrm{VI})$ using $\mathrm{Chi} @ \mathrm{Fe}_{2} \mathrm{O}_{3}-\mathrm{PVDF}$ with a volume of $50 \mathrm{~mL}$, $\mathrm{pH}$ value of 4 , and $\mathrm{Cr}(\mathrm{VI})$ concentration of $0.1 \mathrm{ppm}$. 
There have been several reports about $\mathrm{Cr}(\mathrm{VI})$ removal methods using functionalized nanomaterials. In general, these materials have been applied in the batch system for removal of target metal ions and thus, the metal-containing adsorbents should be recovered from water after the purification procedure was accomplished. The nanoadsorbentsembedded composite membrane used in this study does not require the recovery of adsorbents from water, and therefore, this approach can provide a more convenient purification procedure than the batch process. It should be noted that with a single filtration process using Chi@ $\mathrm{Fe}_{2} \mathrm{O}_{3}-\mathrm{PVDF}, \mathrm{Cr}(\mathrm{VI})$ can be quickly removed with high efficiency, rendering this system as a method of choice for efficient water treatment (Table S1).

\section{Conclusions}

In this study, a new adsorption membrane was fabricated by immobilizing chitosancoated iron oxide on a hydrophilic poly(vinylidene fluoride) membrane to effectively remove toxic substances in an aqueous solution. Through SEM-EDX analysis, it was confirmed that nanoparticles were successfully immobilized in the PVDF membrane sheet. The optimized $\mathrm{pH}$ condition with the highest removal efficiency for the $\mathrm{Cr}(\mathrm{VI})$ of $\mathrm{Chi} @ \mathrm{Fe}_{2} \mathrm{O}_{3}-$ PVDF was $\mathrm{pH} 4$, and pretreated $\mathrm{Chi} @ \mathrm{Fe}_{2} \mathrm{O}_{3}-\mathrm{PVDF}$ showed a higher removal efficiency than that of general Chi@Fe $\mathrm{O}_{3}-\mathrm{PVDF}$ under acidic conditions. The Chi@ $\mathrm{Fe}_{2} \mathrm{O}_{3}-\mathrm{PVDF}$ exhibited $14.104 \mathrm{mg} / \mathrm{g}$ of adsorption capacity in continuous in-flow conditions. In the presence of competing ions, there was a slight decrease in the $\mathrm{Cr}(\mathrm{VI})$ removal efficiency of $\mathrm{Chi@Fe} \mathrm{O}_{3}-\mathrm{PVDF}$, except for $\mathrm{PO}_{4}{ }^{3-}$ ions that interact with both the chitosan functional groups and the iron oxide nanoparticles. The removal efficiency in the real water samples was high without any significant differences from the $\mathrm{Cr}(\mathrm{VI})$ removal efficiency in deionized water. These results indicate that $\mathrm{Chi} @ \mathrm{Fe}_{2} \mathrm{O}_{3}-\mathrm{PVDF}$ has high potential for removal of heavy metals from aqueous solutions.

Supplementary Materials: The following supporting information can be downloaded at https:// www.mdpi.com/article/10.3390/toxics10020098/s1, Figure S1: Procedure for the preparation of the composite membrane (Chi@ $\mathrm{Fe}_{2} \mathrm{O}_{3}-\mathrm{PVDF}$ ) via a vacuum filtration; Figure S2: Linear relationship of the absorbance at $540 \mathrm{~nm}$ with the concentrations of $\mathrm{Cr}(\mathrm{VI})$ in water by the standard diphenylcarbazide method; Figure S3: Linear relationship of the absorbance at $370 \mathrm{~nm}$ with the concentrations of $\mathrm{Cr}(\mathrm{VI})$ in water by direct method; Figure S4: Adsorption isotherm for continuous in-flow experiment (a) Langmuir model, (b) Freundlich model; Table S1: Comparison of other adsorption methods for the removal of $\mathrm{Cr}(\mathrm{VI})$ from aqueous solution.

Author Contributions: Conceptualization, J.J.; methodology, J.J.; formal analysis, C.K.; investigation, J.E.P. and J.-H.S.; resources, S.-J.C.; writing-original draft preparation, J.E.P. and J.-H.S.; writingreview and editing, J.J.; supervision, J.J.; project administration, W.O. and J.K.; funding acquisition, J.K. All authors have read and agreed to the published version of the manuscript.

Funding: This work was supported by the Korea Institute of Energy Technology Evaluation and Planning (KETEP) and the Ministry of Trade, Industry and Energy (MOTIE) of the Republic of Korea (No. 20191510301310).

Institutional Review Board Statement: Not applicable.

Informed Consent Statement: Not applicable.

Data Availability Statement: The data presented in this article are available on request from the corresponding authors.

Conflicts of Interest: The authors declare no conflict of interest.

\section{References}

1. Dinker, M.K.; Kulkarni, P.S. Recent advances in silica-based materials for the removal of hexavalent chromium: A Review. J. Chem. Eng. Data 2015, 60, 2521-2540. [CrossRef]

2. Lui, W.E.; Yang, L.; Xu, S. Efficient removal of hexavalent chromium from water by an adsorption-reduction mechanism with sandwiched nanocomposites. RSC Adv. 2018, 8, 15087-15093. [CrossRef] 
3. Liu, Y.; Luo, C.; Cui, G.; Yan, S. Synthesis of manganese dioxide/iron oxide/graphene oxide magnetic nanocomposites for hexavalent chromium removal. RSC Adv. 2015, 5, 54156-54164. [CrossRef]

4. Mahmoud, M.R.; Lazaridis, N.K. Simultaneous removal of Nickel(II) and Chromium(VI) from aqueous solutions and simulated wastewaters by foam separation. Sep. Sci. Technol. 2015, 50, 1421-1432. [CrossRef]

5. Kim, C.; Kim, H. Study on chemical decontamination process based on permanganic acid-oxalic acid to remove oxide layer deposited in primary system of nuclear power plant. J. Nucl. Fuel Cycle Waste Technol. 2019, 17, 15-28. [CrossRef]

6. Amdur, M.O.; Doull, J.; Klaassen, C.D. Casarett and Doull's toxicology. J. Occup. Med. 1993, 35, 76.

7. Fang, J.; Gu, Z.; Gang, D.; Liu, C.; Ilton, E.S.; Deng, B. Cr(VI) removal from aqueous solution by actovated carbon coated with quaternized poly(4-vinylpyridine). Environ. Sci. Technol. 2007, 41, 4748-4753. [CrossRef]

8. Zhitkovich, A. Chromium in drinking water: Sources, metabolism, and cancer risks. Chem. Res. Toxicol. 2011, 24, 1617-1629. [CrossRef]

9. Golder, A.K.; Chanda, A.K.; Samanta, A.N.; Ray, S. Removal of hexavalent chromium by electrochemical reduction-precipitation: Investigation of process performance and reaction stoichiometry. Separation and purification technology. Sep. Purif. Technol. 2011, 76, 345-350. [CrossRef]

10. Kongsricharoern, N.; Polpracert, C. Chromium removal by a bipolar electro-chemical precipitation process. Water Sci. Technol. 1996, 34, 109-116. [CrossRef]

11. Zhang, X.; Ren, B.; Wu, X.; Yan, X.; Sun, Y.; Gao, H.; Qu, F. Efficient removal of Chromium(VI) using a novel waste biomass chestnut shell-based carbon electrode by electrosorption. ACS Omega 2021, 6, 25389-25396. [CrossRef] [PubMed]

12. Çimen, A. Removal of chromium from wastewater by reverse osmosis. Russ. J. Phys. Chem. 2015, 89, 1238-1243. [CrossRef]

13. Yoon, J.; Amy, G.; Chung, J.; Sohn, J.; Yoon, Y. Removal of toxic ions (chromate, arsenate, and perchlorate) using reverse osmosis, nanofiltration, and ultrafiltration membranes. Chemosphere 2009, 77, 228-235. [CrossRef] [PubMed]

14. Li, G.; Qin, F.; Wang, R.; Xiao, S.; Sun, H.; Chen, R. BiOX (X=Cl, Br, I) nanostructures: Mannitol-mediated microwave synthesis, visible light photocatalytic performance, and Cr(VI) removal capacity. J. Colloid Interface Sci. 2013, 409, 43-51. [CrossRef] [PubMed]

15. Rengaraj, S.; Joo, C.K.; Kim, Y.; Yi, J. Kinetics of removal of chromium from water and electronic process wastewater by ion exchange resins: 1200H, 1500H and IRN97H. J. Hazard. Mater. 2003, 102, 257-275. [CrossRef]

16. Alothman, Z.A.; Allam, M.M.; Naushad, M. Heavy toxic metal ion exchange kinetics: Validation of ion exchange process on composite cation exchanger nylon 6,6 Zr(IV) phosphate. J. Ind. Eng. Chem. 2013, 19, 956-960. [CrossRef]

17. Gupta, V.K.; Agarwal, S.; Saleh, T.A. Chromium removal by combining the magnetic properties of iron oxide with adsorption properties of carbon nanotubes. Water Res. 2011, 45, 2207-2212. [CrossRef]

18. Singaraj, S.G.; Mahanty, B.; Balachandran, D.; Padmaprabha, A. Adsorption and desorption of chromium with humic acid coated iron oxide nanoparticles. Environ. Sci. Pollut. Res. Int. 2019, 26, 30044-30054. [CrossRef]

19. Luo, C.; Tian, Z.; Yang, B.; Zang, L.; Yan, S. Manganese dioxide/iron oxide/acid oxidized multi-walled carbon nanotube magnetic nanocomposite for enhanced hexavalent chromium removal. Chem. Eng. J. 2013, 234, 256-265. [CrossRef]

20. Gallo-Cordova, A.; Morales, M.D.; Mazarío, E. Effect of the surface charge on the adsorption capacity of Chromium(VI) of iron oxide magnetic nanoparticles prepared by microwave-assisted synthesis. Water 2019, 11, 2372. [CrossRef]

21. Egodawatte, S.; Datt, A.; Burns, E.A.; Larsen, S.C. Chemical insight into the adsorption of chromium(III) on iron oxide/mesoporous silica nanocomposites. Langmuir 2015, 31, 7553-7562. [CrossRef] [PubMed]

22. Altun, T.; Ecevit, H. Cr(VI) removal using $\mathrm{Fe}_{2} \mathrm{O}_{3}$-chitosan-cherry kernel shell pyrolytic charcoal composite beads. Environ. Eng. Res. 2020, 25, 426-438. [CrossRef]

23. Marques Neto, J.O.; Bellato, C.R.; Silva, D.C. Iron oxide/carbon nanotubes/chitosan magnetic composite film for chromium species removal. Chemosphere 2019, 218, 391-401. [CrossRef] [PubMed]

24. Subedi, N.; Lähde, A.; Abu-Danso, E.; Iqbal, J.; Bhatnagar, A. A comparative study of magnetic chitosan (Chi@Fe3O4) and graphene oxide modified magnetic chitosan (Chi@Fe3O4GO) nanocomposites for efficient removal of Cr(VI) from water. Int. J. Biol, Macromol. 2019, 137, 948-959. [CrossRef]

25. Zhang, B.; Hu, R.; Sun, D.; Wu, T.; Li, Y. Fabrication of chitosan/magnetite-graphene oxide composites as a novel bioadsorbent for adsorption and detoxification of $\mathrm{Cr}(\mathrm{VI})$ from aqueous solution. Sci. Rep. 2018, 8, 15397. [CrossRef]

26. Muthumareeswaran, M.R.; Alhoshan, M.; Agarwal, G.P. Ultrafiltration membrane for effective removal of chromium ions from potable water. Sci. Rep. 2017, 7, 41423. [CrossRef]

27. Geise, G.M.; Lee, H.-S.; Miller, D.J.; Freeman, B.D.; McGrath, J.E.; Paul, D.R. Water purification by membranes: The role of polymer science. J. Polym. Sci. B Polym. Phys. 2010, 48, 1685-1718. [CrossRef]

28. Ertas, Y.; Uyar, T. Fabrication of cellulose acetate/polybenzoxazine cross-linked electrospun nanofibrous membrane for water treatment. Carbohydr. Polym. 2017, 177, 378-387. [CrossRef]

29. Shim, H.E.; Yang, J.E.; Jeong, S.W.; Lee, C.H.; Song, L.; Mushtaq, S.; Choi, D.S.; Choi, Y.J.; Jeon, J. Silver nanomaterial-immobilized desalination systems for efficient removal of radioactive iodine species in water. Nanomaterials 2018, 8, 660. [CrossRef]

30. Aizawa, K.; Gantt, E. Rapid method for assay of quantitative binding of soluble proteins and photosynthetic membrane proteins on poly(vinylidene difluoride) membranes. Anal. Chim. Acta 1998, 365, 109-113. [CrossRef]

31. Hoefs, J. Stable Isotope Geochemistry; Springer: Berlin/Heidelberg, Germany; Gottingen, Germany, 2009.

32. Sankararamakrishnan, N.; Dixit, A.; Iyengar, L.; Sanghi, R. Removal of hexavalent chromium using a novel cross linked xanthated chitosan. Bioresour. Technol. 2006, 97, 2377-2382. [CrossRef] [PubMed] 
33. Park, J.E.; Shim, H.E.; Mushtaq, S.; Choi, Y.J.; Jeon, J. A Functionalized nanocomposite adsorbent for the sequential removal of radioactive iodine and cobalt ions in aqueous media. Korean J. Chem. Eng. 2020, 37, 2209-2215. [CrossRef]

34. Mushtaq, S.; Yun, S.-J.; Yang, J.E.; Jeong, S.-W.; Shim, H.E.; Choi, M.H.; Park, S.H.; Choi, Y.J.; Jeon, J. Efficient and selective removal of radioactive iodine anions using engineered nanocomposite membranes. Environ. Sci. Nano 2017, 4, 2157-2163. [CrossRef]

35. Lace, A.; Ryan, D.; Bowkett, M.; Cleary, J. Chromium monitoring in water by colorimetry using optimised 1,5-diphenylcarbazide method. Int. J. Environ. Res. Public Health 2019, 16, 1803. [CrossRef]

36. Samrot, A.V.; Sahithya, C.S.; Selvarani, A.J.; Pachiyappan, S.; Kumar, S.S. Surface-engineered super-paramagnetic iron oxide nanoparticles for chromium removal. Int. J. Nanomed. 2019, 14, 8105-8119. [CrossRef]

37. Bhaumik, M.; Agarwal, S.; Gupta, V.K.; Maity, A. Enhanced removal of $\mathrm{Cr}(\mathrm{VI})$ from aqueous solutions using polypyrrole wrapped oxidized MWCNTs nanocomposites adsorbent. J. Colloid Interface Sci. 2016, 470, 257-267. [CrossRef]

38. Shalaby, T.I.; Fikrt, N.M.; Mohamed, M.M.; El Kady, M.F. Preparation and characterization of iron oxide nanoparticles coated with chitosan for removal of $\mathrm{Cd}(\mathrm{II})$ and $\mathrm{Cr}(\mathrm{VI})$ from aqueous solution. Water Sci. Technol. 2014, 70, 1004-1010. [CrossRef]

39. Almasri, D.A.; Saleh, N.B.; Atieh, M.A.; McKay, G.; Ahzi, S. Adsorption of phosphate on iron oxide doped halloysite nanotubes. Sci. Rep. 2019, 9, 3232. [CrossRef]

40. Shahid, M.K.; Kim, Y.; Choi, Y.-G. Magnetite synthesis using iron oxide waste and its application for phosphate adsorption with column and batch reactors. Chem. Eng. Res. Des. 2019, 148, 169-179. [CrossRef] 